Check for updates

Cite this: RSC Adv., 2019, 9, 23589

Received 26th May 2019

Accepted 15th July 2019

DOI: 10.1039/c9ra03983j

rsc.li/rsc-advances

\section{The relationship between activation-passivation transition and grain boundary dissolution on four steel samples in acidic solutions containing $\mathrm{NO}_{2}{ }^{-}$}

\begin{abstract}
Yong Zhou, (D) *a Pei Zhang, ${ }^{b}$ Jinping Xiong ${ }^{\mathrm{c}}$ and Fuan Yan ${ }^{\mathrm{a}}$
Herein, for four steels ( $\mathrm{L} 80, \mathrm{~N} 80, \mathrm{X} 65$ and Q235) in acidic solutions $\left(\mathrm{HNO}_{3}, \mathrm{HCl}, \mathrm{HAC}\right.$ and $\left.\mathrm{CO}_{2}\right)$ containing $\mathrm{NO}_{2}{ }^{-}$, the relationship between the activation-passivation (A-P) transition and the grain boundary dissolution (GBD) was studied by potentiodynamic polarization curve (PPC) measurements and scanning electron microscopy (SEM) observations. In the specific $\mathrm{pH}$ range of acidic solutions, where the four steels showed an electrochemical characteristic of the A-P transition, GBD was observed on the steel surface; however, at low or high $\mathrm{pH}$ values of the acidic solutions, the four steels respectively showed the electrochemical behavior of activation (A) or self-passivation (sP), and GBD was not observed on the steel surface. The effects of the acid type, $\mathrm{pH}$ value and steel type on the electrochemical characteristic of the A-P transition and the occurrence of GBD were also discussed in detail. Via this study, it was confirmed that under the electrochemical characteristic of the A-P transition, the occurrence of GBD was a general corrosion behavior of carbon steels and alloy steels in acidic solutions containing $\mathrm{NO}_{2}{ }^{-}$.
\end{abstract}

\section{Introduction}

Steel products are widely applied in the fields of production and living; ${ }^{1-3}$ however, the problems of corrosion and failure inevitably limit their application and development, ${ }^{4-6}$ which are due to the presence of aggressive species in service environments. ${ }^{7-9}$

In the electrochemical process of steel corrosion, the main cathodic reaction is $\mathrm{H}^{+}$reduction or $\mathrm{O}_{2}$ reduction, which is very closely related to the solution $\mathrm{pH}$ value. In strongly acidic solutions (relatively low $\mathrm{pH}$ ), the dominant cathodic reaction is the $\mathrm{H}^{+}$reduction with the standard potential $\left(E_{\mathrm{st}}\right)$ of -0.244 $\mathrm{V}_{\mathrm{SCE}}:^{\mathbf{1 0}}$

$$
2 \mathrm{H}^{+}+2 \mathrm{e} \rightarrow \mathrm{H}_{2}\left(E_{\mathrm{st}}=-0.244 \mathrm{~V}_{\mathrm{SCE}}\right)
$$

According to the Nernst equation, the equilibrium potential $\left(E_{\text {eq }}\right)$ of $\mathrm{H}^{+}$reduction can be described as follows: ${ }^{11}$

$$
E_{\text {eq } / \mathrm{SCE}}\left(\mathrm{H}^{+} / \mathrm{H}_{2}\right)=-0.244-0.059 \mathrm{pH}
$$

In contrast, in weakly acidic and alkaline solutions (relatively high $\mathrm{pH}$ ), the $\mathrm{O}_{2}$ reduction with the $E_{\mathrm{st}}$ of $0.157 \mathrm{~V}_{\mathrm{SCE}}$ becomes the dominant cathodic reaction: ${ }^{10}$

$$
\mathrm{O}_{2}+2 \mathrm{H}_{2} \mathrm{O}+4 \mathrm{e} \rightarrow 4 \mathrm{OH}^{-}\left(E_{\mathrm{st}}=-0.157 \mathrm{~V}_{\mathrm{SCE}}\right)
$$

${ }^{a}$ Key Laboratory for Green Chemical Process of Ministry of Education, Wuhan Institute of Technology, Wuhan 430205, China.E-mail: zhouyong@wit.edu.cn ${ }^{b}$ College of Chemistry and Food Science, Yulin Normal University, Yulin 537000, China ${ }^{c}$ Beijing Key Laboratory of Electrochemical Process and Technology for Materials, Beijing University of Chemical Technology, Beijing 100029, China
The $E_{\text {eq }}$ of $\mathrm{O}_{2}$ reduction can be depicted as follows: ${ }^{11}$

$$
E_{\text {eq } / \mathrm{SCE}}\left(\mathrm{O}_{2} / \mathrm{OH}^{-}\right)=0.984-0.059 \mathrm{pH}
$$

It is speculated that the following anodic reaction of Fe oxidation is independent of the solution $\mathrm{pH}$ value:

$$
\mathrm{Fe} \rightarrow \mathrm{Fe}^{2+}+2 \mathrm{e}\left(E_{\mathrm{st}}=-0.684 \mathrm{~V}_{\mathrm{SCE}}\right)
$$

With an increase in the $\mathrm{pH}$ value, the $E_{\text {eq }}$ for both the $\mathrm{H}^{+}$ reduction (eqn (2)) and the $\mathrm{O}_{2}$ reduction (eqn (4)) would decline; this would result in the negative shift of the corrosion potential $\left(E_{\text {corr }}\right)$ in the polarization curve. In addition, the left shift of the chemical equilibrium for the $\mathrm{H}^{+}$reduction (eqn (1)) and the $\mathrm{O}_{2}$ reduction (eqn (3)) would occur, resulting in a decrease in the corrosion current density $\left(i_{\text {corr }}\right)$ in the polarization curve. Related studies involving the abovementioned discussion have been repeatedly reported. ${ }^{\mathbf{1 2 - 1 4}}$

On the other hand, intergranular corrosion (IGC) is a common and important type of localized corrosion for metals and alloys, which is attributed to the establishment of an electrochemical micro-couple between grain interiors (GIs) and grain boundaries (GBs).$^{15}$ At present, studies on IGC are mainly focused on stainless steels $(\mathrm{SSs})^{16-20}$ and aluminum alloys (AAs); ${ }^{21-25}$ this is due to high IGC susceptibility of SSs and AAs derived from the precipitation of harmful phases along GBs during the process of inappropriate thermal treatment. For SSs, precipitates such as $\mathrm{Cr}_{23} \mathrm{C}_{6},{ }^{16} \mathrm{CrN} / \mathrm{Cr}_{2} \mathrm{~N},{ }^{17} \sigma$ phase,${ }^{18} \chi$ phase, ${ }^{19}$ and $\pi$ phase $^{20}$ have been reported to result in IGC susceptibility. Moreover, the IGC susceptibility of AAs has been reported to 
result from the precipitation of the $\theta$ phase, ${ }^{21} \mathrm{~S}$ phase, ${ }^{22}$ $\beta$ phase, ${ }^{23}$ T phase, ${ }^{24} \eta$ phase ${ }^{25}$ and other similar phases; due to the presence of IGC susceptibility, the electrochemical microcouple between GIs and GBs can be spontaneously established when SSs and AAs are applied in corrosive environments, thus inducing the occurrence of IGC. ${ }^{26}$

Except for SSs, IGC susceptibility is not prominent in other types of steel, and relatively few studies have been reported on IGC. In a previous study, for the Q235 carbon steel in a $\mathrm{CO}_{2}-$ $\mathrm{NaNO}_{2}$ solution, the occurrence of the grain boundary dissolution (GBD) was observed on the steel surface when the Q235 steel was polarized in the activation-passivation (A-P) region. ${ }^{27}$ Subsequent studies further confirmed the occurrence of GBD on the surface of carbon steels when this type of steel was polarized in the A-P region in acidic solutions containing $\mathrm{NO}_{2}{ }^{-}$ such as a $\mathrm{CO}_{2}-\mathrm{NaNO}_{2}$ solution, ${ }^{28} \mathrm{HNO}_{3}-\mathrm{NaNO}_{2}$ solution ${ }^{29}$ and $\mathrm{HCl}-\mathrm{NaNO}_{2}$ solution. ${ }^{30}$ However, to date, it is not clear that in acidic solutions containing $\mathrm{NO}_{2}{ }^{-}$, whether the occurrence of GBD is a special corrosion behavior of carbon steels or a general corrosion behavior of other steels, particularly alloy steels. To clarify the abovementioned statement, in this study, three low alloy steels (L80, N80 and X65) were chosen to study the relationship between the electrochemical characteristic of the A-P transition and the occurrence of GBD in four acidic solutions $\left(\mathrm{HNO}_{3}, \mathrm{HCl}, \mathrm{HAc}\right.$ and $\left.\mathrm{CO}_{2}\right)$ containing $\mathrm{NO}_{2}{ }^{-}$. Electrochemical measurements using a potentiodynamic polarization curve (PPC) and microstructural observation using a scanning electron microscope (SEM) were carried out; in addition, to understand the difference between the A-P transition and GBD of carbon steel and alloy steel, the PPC measurement and the SEM observation for the Q235 steel were performed.

\section{Experimental}

The detailed chemical composition of the L80, N80, X65 and Q235 steels is listed in Table 1. Herein, four steel samples were manually abraded up to 1000 grit with SiC abrasive papers, rinsed with deionized water and degreased in acetone.

The tested solutions were four acidic solutions containing $\mathrm{NO}_{2}{ }^{-}: \mathrm{HNO}_{3}-\mathrm{NaNO}_{2}, \mathrm{HCl}-\mathrm{NaNO}_{2}, \mathrm{HAc}-\mathrm{NaNO}_{2}$ and $\mathrm{CO}_{2}{ }^{-}$ $\mathrm{NaNO}_{2}$. For the first three solutions, the diluted $\mathrm{HNO}_{3}, \mathrm{HCl}$ and HAc solutions were introduced into a $0.01 \mathrm{M} \mathrm{NaNO}_{2}$ solution to adjust the $\mathrm{pH}$ value. For the $\mathrm{CO}_{2}-\mathrm{NaNO}_{2}$ solution, the $\mathrm{CO}_{2}$ gas was purged into a $0.01 \mathrm{M} \mathrm{NaNO}_{2}$ solution until the $\mathrm{CO}_{2}$ saturated condition was reached and the $\mathrm{pH}$ value of the $\mathrm{CO}_{2}{ }^{-}$ $\mathrm{NaNO}_{2}$ solution was 3.7.31

The PPC tests were carried out using the CS310 electrochemical workstation. A typical three-electrode system was applied, and the system was composed of a saturated calomel electrode (SCE) as the reference electrode, a platinum sheet as the counter electrode and a steel sample as the working electrode. Before each PPC test, the working electrode was immersed in the corresponding tested solution for $30 \mathrm{~min}$ to ensure a stable condition of the open circuit potential (OCP). The potential scanning rate was $0.1 \mathrm{mV} \mathrm{s}^{-1}$, and the potential scanning range was from $-0.3 \mathrm{~V}_{\mathrm{OCP}}$ to the potential value corresponding to the occurrence of transpassivation or pitting. All the PPC tests were performed at ambient temperature. After this, the surface morphologies of the four steel samples were observed by the LEO-1450 SEM instrument.

\section{Results and discussion}

Fig. 1 shows the PPCs of L80, N80, X65 and Q235 steels in $\mathrm{HNO}_{3}-\mathrm{NaNO}_{2}, \mathrm{HCl}-\mathrm{NaNO}_{2}$ and $\mathrm{HAc}-\mathrm{NaNO}_{2}$ solutions with $0.01 \mathrm{M} \mathrm{NaNO}_{2}$ and different $\mathrm{pH}$ values. The effects of the acid type, $\mathrm{pH}$ value and steel type on the electrochemical behaviors were investigated, and the following five electrochemical behaviors were demonstrated in the PPCs: activation-passivation-transpassivation $\quad(\mathrm{A}-\mathrm{P}-\mathrm{T}), \quad$ self-passivation-transpassivation ( $\mathrm{SP}-\mathrm{T})$, activation $(\mathrm{A})$, activation-passivation-pitting (A-P-P), and self-passivation-pitting (sP-P). The detailed results of the electrochemical behavior are presented in Table 2 .

According to previous studies, ${ }^{27-30}$ for carbon steels in acidic solutions containing $\mathrm{NO}_{2}{ }^{-}$, the initiation and propagation of GBD occurs on the steel surface when the carbon steels are polarized in the A-P region. Based on the results shown in Fig. 1 and Table 2, the electrochemical characteristic of the A-P transition, including $\mathrm{A}-\mathrm{P}-\mathrm{T}$ and $\mathrm{A}-\mathrm{P}-\mathrm{P}$, was also observed in the PPCs for the following cases: from $\mathrm{pH} 1$ to $\mathrm{pH} 4$ in $\mathrm{HNO}_{3}-$ $\mathrm{NaNO}_{2}$ solutions, at pH 3 and $\mathrm{pH} 4$ in $\mathrm{HCl}-\mathrm{NaNO}_{2}$ solutions and at $\mathrm{pH} 3$ and $\mathrm{pH} 4$ in $\mathrm{HAc}-\mathrm{NaNO}_{2}$ solutions.

To confirm the occurrence of GBD, four steels were polarized to different potential values according to their electrochemical behaviors: in the cases of A-P-T and A-P-P, the steels were polarized to the initial passivation potential (marked in Fig. 1a and e); in the case of $\mathrm{sP}-\mathrm{T}$, the steels were polarized to the transpassivation potential (marked in Fig. 1b); in the case of $\mathrm{sP}-\mathrm{P}$, the steels were polarized to the pitting potential (marked in Fig. 1f); and in the case of $\mathrm{A}$, the steels were polarized to the anodic potential value equal to the pitting potential. After this, SEM was applied to observe the surface morphologies. To facilitate comparison, the detailed results of the SEM observation are also listed in Table 2. Based on the results shown in Table 2, under the electrochemical characteristic of the A-P transition, an obvious corrosion dissolution along the GBs has been observed on the steel surface, indicating that the

Table 1 Detailed chemical composition of the L80, N80, X65 and Q235 steels

\begin{tabular}{|c|c|c|c|c|c|c|c|c|c|c|c|}
\hline Steel & $\mathrm{C}$ & $\mathrm{Mn}$ & $\mathrm{P}$ & S & $\mathrm{Si}$ & $\mathrm{Cr}$ & Mo & $\mathrm{Ni}$ & $\mathrm{Cu}$ & $\mathrm{Al}$ & $\mathrm{Fe}$ \\
\hline L80 & 0.190 & 1.370 & 0.010 & 0.004 & 0.230 & 0.024 & 0.034 & 0.023 & 0.023 & 0.036 & Balance \\
\hline N80 & 0.240 & 1.280 & 0.015 & 0.015 & 0.310 & 0.015 & 0.026 & 0.026 & 0.015 & 0.020 & Balance \\
\hline X65 & 0.030 & 1.510 & 0.024 & 0.005 & 0.170 & 0.038 & 0.016 & 0.025 & 0.040 & 0.020 & Balance \\
\hline Q235 & 0.160 & 0.530 & 0.015 & 0.045 & 0.300 & - & - & - & - & - & Balance \\
\hline
\end{tabular}




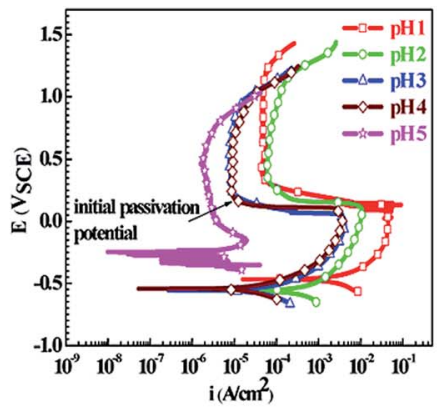

(a)

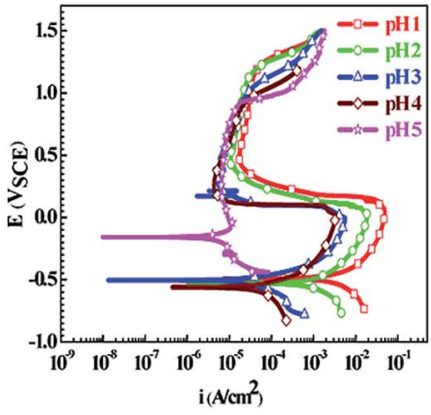

(d)

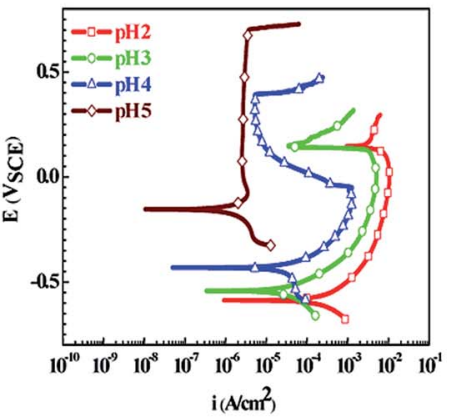

(g)

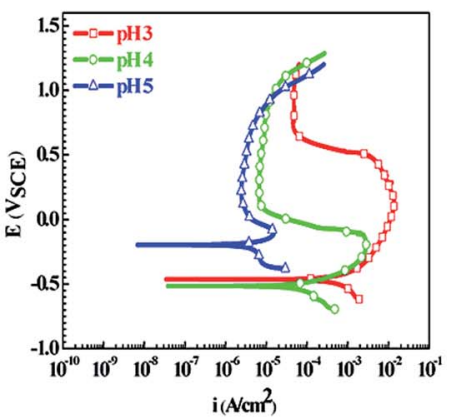

(j)

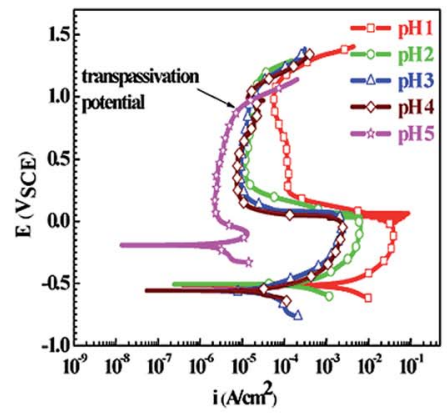

(b)

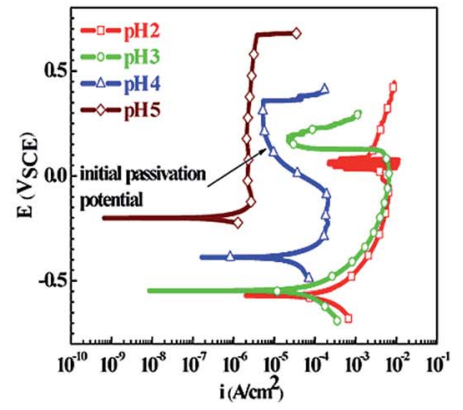

(e)

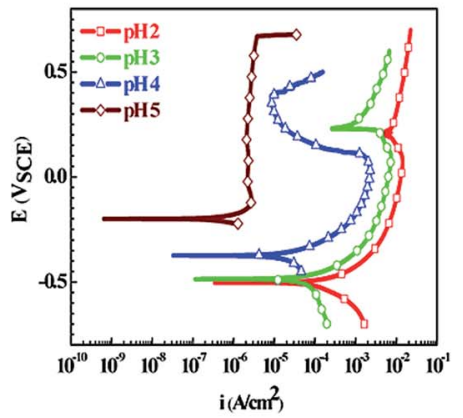

(h)

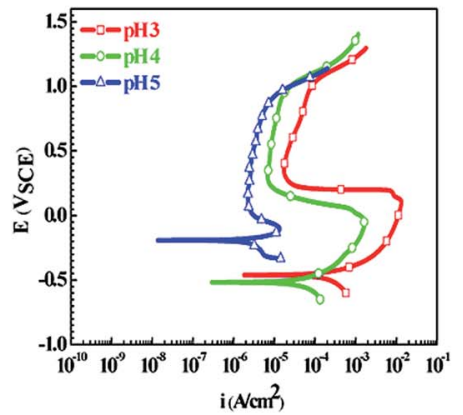

(k)

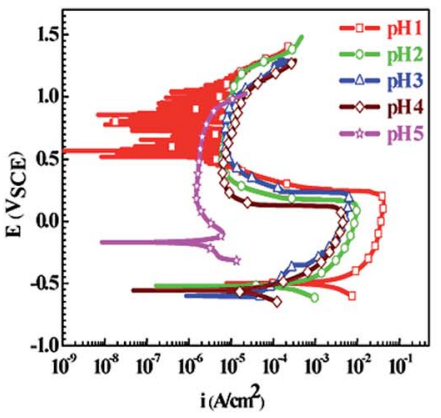

(c)

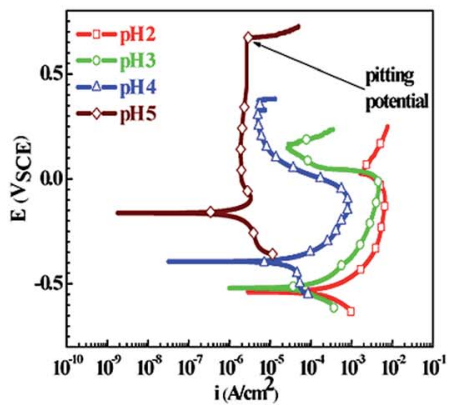

(f)

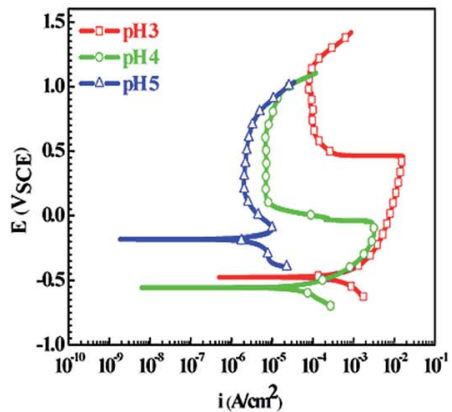

(i)

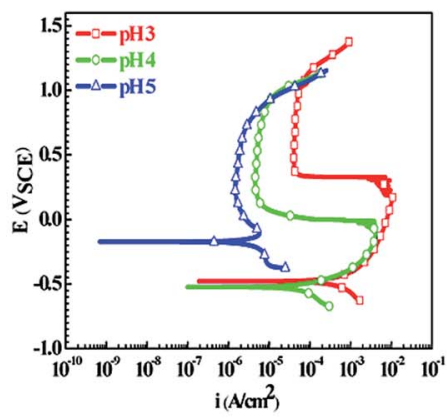

(l)

Fig. 1 Potentiodynamic polarization curves of the L80, N80, X65 and Q235 steels in $\mathrm{HNO}_{3}-\mathrm{NaNO}_{2}, \mathrm{HCl}-\mathrm{NaNO} \mathrm{O}_{2}$ and $\mathrm{HAc}-\mathrm{NaNO} \mathrm{N}_{2}$ solutions with $0.01 \mathrm{M} \mathrm{NaNO}_{2}$ and different pH values: (a) $\mathrm{L} 80-\mathrm{HNO}_{3}-\mathrm{NaNO}_{2}$, (b) $\mathrm{N} 80-\mathrm{HNO}_{3}-\mathrm{NaNO}_{2}$, (c) $\mathrm{X} 65-\mathrm{HNO}_{3}-\mathrm{NaNO}_{2}$, (d) $\mathrm{Q}_{2} 35-\mathrm{HNO}_{3}-\mathrm{NaNO}_{2}$, (e) $\mathrm{L} 80-\mathrm{HCl}-\mathrm{NaNO}_{2}$, (f) $\mathrm{N} 80-\mathrm{HCl}-\mathrm{NaNO}_{2}$, (g) X65-HCl-NaNO${ }_{2}$, (h) Q235- HCl-NaNO${ }_{2}$, (i) $\mathrm{L} 80-\mathrm{HAc}-\mathrm{NaNO}$, (j) N80-HAc-NaNO , (k) X65$\mathrm{HAC}-\mathrm{NaNO}_{2}$ and (l) Q235- $\mathrm{HAC}-\mathrm{NaNO}_{2}$.

occurrence of GBD is a general corrosion behavior for the L80, N80 and X65 steels, rather than a special corrosion behavior as in the case of the Q235 steel. Moreover, the presence of non-uniform passive films, mechanical scratches and corrosion pits was observed on the steel surface under the electrochemical behaviors of $\mathrm{SP}-\mathrm{T}, \mathrm{A}$ and $\mathrm{SP}-\mathrm{P}$, respectively. 
Table 2 Electrochemical behaviors and SEM morphologies of the L80, N80, X65 and Q235 steels polarized to different potential values in $\mathrm{HNO}_{3}-\mathrm{NaNO}_{2}, \mathrm{HCl}-\mathrm{NaNO}_{2}$ and $\mathrm{HAC}-\mathrm{NaNO}_{2}$ solutions with $0.01 \mathrm{M} \mathrm{NaNO}_{2}$ and different $\mathrm{pH}$ values

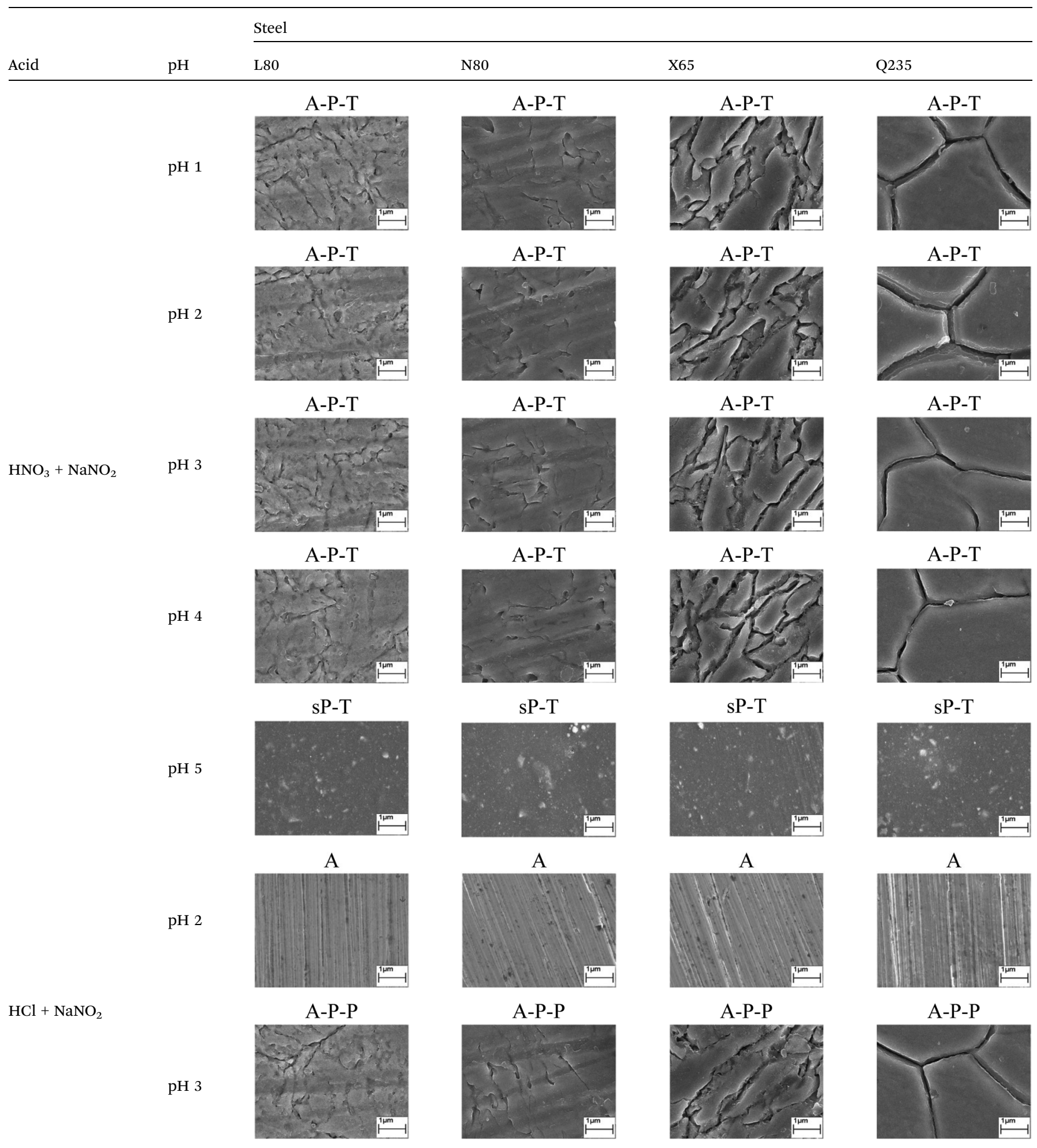


Table 2 (Contd.)

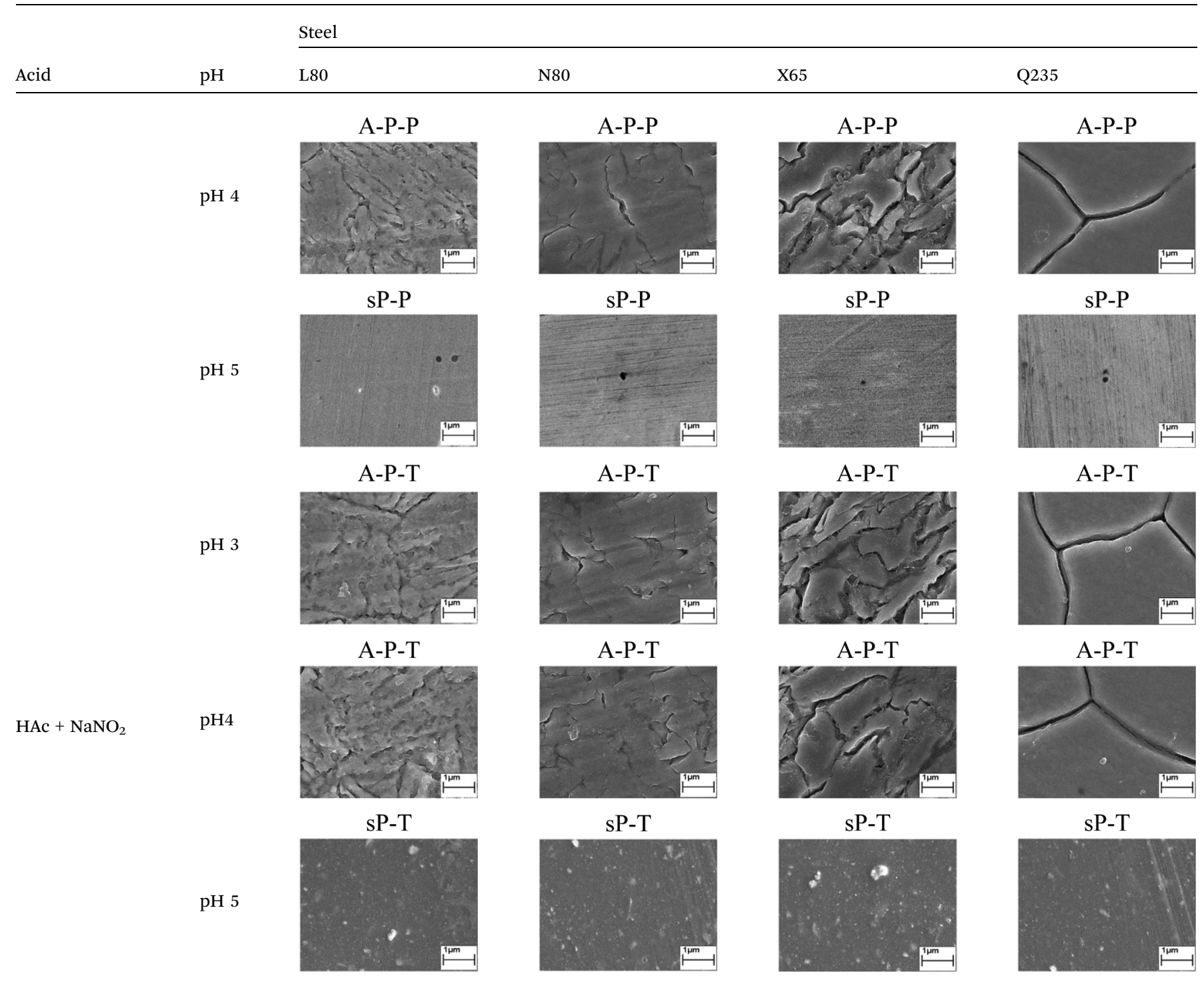

As observed from the abovementioned results, the relationship between the electrochemical characteristic of the A-P transition and the occurrence of GBD for the L80, N80, X65 and Q235 steels in $\mathrm{HNO}_{3}-\mathrm{NaNO}_{2}, \mathrm{HCl}-\mathrm{NaNO}_{2}$ and $\mathrm{HAc}-\mathrm{NaNO}_{2}$ solutions was very close. The appearance of the A-P transition in the PPC indicated the occurrence of GBD on the steel surface and vice versa. However, note that the effects of the acid type, $\mathrm{pH}$ value and steel type on the electrochemical behaviors were very significant and have been discussed hereinafter.

For the L80 steel in the pH 2 solutions, the electrochemical behaviors of A-P-T and A were respectively shown in the PPCs in the $\mathrm{pH} 2 \mathrm{HNO}_{3}-\mathrm{NaNO}_{2}$ solution and $\mathrm{pH} 2 \mathrm{HCl}-\mathrm{NaNO}_{2}$ solution, which were mainly attributed to the difference in the oxidability and the components $\mathrm{HNO}_{3}$ and $\mathrm{HCl} \cdot \mathrm{HNO}_{3}$ showed both strong oxidability and strong acidity. In contrast, $\mathrm{HCl}$ did not show oxidability and strong acidity. Moreover, the inhibition of $\mathrm{NO}_{3}{ }^{-}$and the aggression of $\mathrm{Cl}^{-}$in corrosive environments were reported. $\mathrm{NO}_{3}{ }^{-}$promoted passivation on the steel surface; ${ }^{32}$ however, $\mathrm{Cl}^{-}$attacked the surface passive film. ${ }^{33}$ Therefore, the presence of the A-P transition in the $\mathrm{pH} 2$ $\mathrm{HNO}_{3}-\mathrm{NaNO}_{2}$ solution and the corresponding absence in the pH $2 \mathrm{HCl}-\mathrm{NaNO}_{2}$ solution was observed. Note that the electrochemical behaviors of the four steels in the $\mathrm{pH} 1 \mathrm{HCl}-\mathrm{NaNO}_{2}$ solution were similar to those in the $\mathrm{pH} 2 \mathrm{HCl}-\mathrm{NaNO}_{2}$ solution. Therefore, the PPC and SEM results in the former solution are not provided herein. Because of the relatively weak acidity of HAc, the pH 1 and pH 2 HAc- $\mathrm{NaNO}_{2}$ solutions could not be obtained. In the $\mathrm{pH} 3$ and $\mathrm{pH} 4$ solutions, the $\mathrm{L} 80$ steel showed the A-P-T, A-P-P and A-P-T behaviors in the $\mathrm{HNO}_{3}-\mathrm{NaNO}_{2}$, $\mathrm{HCl}-\mathrm{NaNO}_{2}$ and $\mathrm{HAc}-\mathrm{NaNO}_{2}$ solutions, respectively. The electrochemical characteristic of the A-P transition was due to the effectiveness of $\mathrm{NO}_{2}{ }^{-}$and the decrease in the $\mathrm{H}^{+}$ 
concentration; ${ }^{34}$ moreover, the presence of $\mathrm{Cl}^{-}$derived from $\mathrm{HCl}$ was responsible for pitting..$^{30}$ In the $\mathrm{pH} 5$ solutions, the lack of the $\mathrm{H}^{+}$concentration contributed to the $\mathrm{SP}-\mathrm{T}$ behavior in the $\mathrm{HNO}_{3}-\mathrm{NaNO}_{2}$ and $\mathrm{HAc}-\mathrm{NaNO}_{2}$ solutions and the SP-P behavior in the $\mathrm{HCl}-\mathrm{NaNO}_{2}$ solution for the L80 steel, which was attributed to the following reaction: ${ }^{35-37}$

$$
2 \mathrm{Fe}^{2+}+2 \mathrm{OH}^{-}+2 \mathrm{NO}_{2}^{-} \rightarrow 2 \mathrm{NO}+\gamma-\mathrm{Fe}_{2} \mathrm{O}_{3}+\mathrm{H}_{2} \mathrm{O}
$$

The effect of the acid type on the electrochemical behavior for the N80, X65 and Q235 steels was similar to that in the case of the L80 steel.

In the $\mathrm{HNO}_{3}-\mathrm{NaNO}_{2}$ solutions, with an increase in the $\mathrm{pH}$ value, the $\mathrm{L} 80$ steel showed the electrochemical behaviors of $\mathrm{A}-\mathrm{P}-\mathrm{T}$ in the $\mathrm{pH} 1-\mathrm{pH} 4$ solutions and $\mathrm{SP}-\mathrm{T}$ in the $\mathrm{pH} 5$ solution. The relatively wide $\mathrm{pH}$ range from $\mathrm{pH} 1$ to $\mathrm{pH} 4$ for the electrochemical characteristic of the A-P transition was attributed to the strong oxidability of $\mathrm{HNO}_{3}$ and the inhibition of $\mathrm{NO}_{3}{ }^{-}$. In contrast, in the $\mathrm{HCl}-\mathrm{NaNO}_{2}$ and $\mathrm{HAc}-\mathrm{NaNO}_{2}$ solutions, the electrochemical characteristic of the A-P transition for the L80 steel was present only in the $\mathrm{pH} 3$ and $\mathrm{pH} 4$ solutions due to the component $\mathrm{HCl}$ and the weak acidity of HAc, which has been explained in the previous discussion. In the $\mathrm{pH} 2 \mathrm{HCl}-\mathrm{NaNO}_{2}$ solution, the absence of the A-P transition for the L80 steel was attributed to the excess $\mathrm{H}^{+}$concentration ${ }^{30}$ and the aggression of $\mathrm{Cl}^{-} .{ }^{33}$ Similarly, the effect of the $\mathrm{pH}$ value on the electrochemical behavior for the N80, X65 and Q235 steels was similar to that for the L80 steel.

Regarding the effect of the steel type on the electrochemical behavior, note that with the same acid type and $\mathrm{pH}$ value, the four steels showed the same electrochemical behavior; this indicated that the composition and alloyed element did not affect the electrochemical characteristic of the A-P transition and the occurrence of GBD. However, the different SEM morphologies were due to the different microstructures of the four steels, which have been studied further.

To further confirm the relationship between the A-P transition and GBD, the four steels were polarized to the initial passivation potential (marked in Fig. 2a) in the $\mathrm{CO}_{2}-\mathrm{NaNO}_{2}$ solution and then observed by SEM. The results of the PPC test and SEM observation are shown in Fig. 2. All four steels showed the electrochemical behavior of A-P-T, and an obvious GBD was observed on the steel surface. For the L80, N80, X65 and Q235 steels, the results obtained in the $\mathrm{CO}_{2}-\mathrm{NaNO}_{2}$ solution were consistent with those obtained in the $\mathrm{HNO}_{3}-\mathrm{NaNO}_{2}, \mathrm{HCl}-$ $\mathrm{NaNO}_{2}$ and HAc-NaNO${ }_{2}$ solutions: GBD could be observed on the steel surface at $\mathrm{pH} 3.7$, which was in the range from $\mathrm{pH} 3$ to pH 4.

However, it should be clarified that in a previous study, it has been reported that the occurrence of GBD is attributed to the combined effects of $\mathrm{CO}_{2}$ and $\mathrm{NO}_{2}{ }^{-}$. $\mathrm{NO}_{2}{ }^{-}$promoted passivation on the surface of the crystal grains, whereas $\mathrm{CO}_{2}$ induced dissolution in the vicinity of the grain boundaries. ${ }^{27}$ In this study, it was concluded that $\mathrm{H}^{+}$, rather than $\mathrm{CO}_{2}$, resulted in the occurrence of GBD in acidic solutions containing $\mathrm{NO}_{2}{ }^{-}$. For the L80, N80, X65 and Q235 steels in the $\mathrm{HNO}_{3}-\mathrm{NaNO}_{2}, \mathrm{HCl}-$ $\mathrm{NaNO}_{2}, \quad \mathrm{HAc}-\mathrm{NaNO}_{2}$ and $\mathrm{CO}_{2}-\mathrm{NaNO}_{2}$ solutions, the relationship between the A-P transition and GBD has been discussed hereinafter.

GBD was observed on the steel surface when the four steels showed the electrochemical behaviors of $\mathrm{A}-\mathrm{P}-\mathrm{T}$ and $\mathrm{A}-\mathrm{P}-\mathrm{P}$. Before the applied potential reached the transpassivation potential and the pitting potential, the PPCs of A-P-T and $\mathrm{A}-\mathrm{P}-\mathrm{P}$ were similar and composed of an activation (A) region, activation-passivation (A-P) region and passivation $(\mathrm{P})$ region. Furthermore, according to previous studies ${ }^{27-30}$ and the current results obtained in this study, the initiation and propagation of GBD occurred before the four steels were polarized in the $\mathrm{P}$ region. Therefore, this study was mainly focused on the anodic and cathodic reactions occurring in the $\mathrm{A}$ region and $\mathrm{A}-\mathrm{P}$ region. Fig. 3 shows a schematic to describe the electrode reactions in the A region and the A-P region. For the L80, N80, X65 and Q235 steels in the $\mathrm{HNO}_{3}-\mathrm{NaNO}_{2}, \mathrm{HCl}-\mathrm{NaNO}_{2}, \mathrm{HAc}-$ $\mathrm{NaNO}_{2}$ and $\mathrm{CO}_{2}-\mathrm{NaNO}_{2}$ solutions, before the applied potential reached the $\mathrm{A}-\mathrm{P}$ transition potential, the dominant anodic and cathodic reactions were Fe oxidation (eqn (5)) and $\mathrm{H}^{+}$reduction (eqn (1)), respectively. With a positive shift of the applied potential, the electrode reactions accelerated. Therefore, the anodic current density gradually increased with potential in the A region until the applied potential reached the A-P transition potential. However, due to the presence of $\mathrm{NO}_{2}{ }^{-}$and the continuously positive shift of the applied potential, the following cathodic reactions involving the $\mathrm{NO}_{2}{ }^{-} / \mathrm{HNO}_{2}$ reduction occurred:

$$
\begin{gathered}
2 \mathrm{NO}_{2}{ }^{-}+8 \mathrm{H}^{+}+6 \mathrm{e} \rightarrow \mathrm{N}_{2}+4 \mathrm{H}_{2} \mathrm{O}\left(E_{\mathrm{st}}=0.944 \mathrm{~V}_{\mathrm{SCE}}\right)^{38} \\
2 \mathrm{HNO}_{2} \rightarrow \mathrm{N}_{2} \mathrm{O}_{4}+2 \mathrm{H}^{+}+2 \mathrm{e}\left(E_{\mathrm{st}}=0.826 \mathrm{~V}_{\mathrm{SCE}}\right)^{11} \\
2 \mathrm{NO}_{2}{ }^{-}+6 \mathrm{H}^{+}+4 \mathrm{e} \rightarrow \mathrm{N}_{2} \mathrm{O}+3 \mathrm{H}_{2} \mathrm{O}\left(E_{\mathrm{st}}=0.728 \mathrm{~V}_{\mathrm{SCE}}\right)^{38} \\
\mathrm{HNO}_{2}+\mathrm{H}_{2} \mathrm{O} \rightarrow \mathrm{NO}_{3}^{-}+3 \mathrm{H}^{+}+2 \mathrm{e}\left(E_{\mathrm{st}}=0.696 \mathrm{~V}_{\mathrm{SCE}}\right)^{11}
\end{gathered}
$$

Moreover, the anodic reaction of $\mathrm{Fe}^{2+}$ oxidation may be possible:

$$
\mathrm{Fe}^{2+} \rightarrow \mathrm{Fe}^{3+}+\mathrm{e}\left(E_{\mathrm{st}}=0.527 \mathrm{~V}_{\mathrm{SCE}}\right)
$$

The reason is that the $E_{\mathrm{st}}$ of $\mathrm{NO}_{2}{ }^{-} / \mathrm{HNO}_{2}$ reductions (eqn (7)(10)) is significantly positive than that of the $\mathrm{Fe}^{2+}$ oxidation (eqn (11)). However, kinetic studies and potential calculations are necessary to verify the actual cathodic reactions of the $\mathrm{NO}_{2}{ }^{-}$/ $\mathrm{HNO}_{2}$ reduction. It is generally accepted that the electrochemical characteristic of the A-P transition is very closely associated with the generation of $\mathrm{Fe}^{3+}$, which is the main component in the surface passive film. ${ }^{39-41}$ With a positive shift of the applied potential, when the applied potential reached up to the A-P transition potential, the anodic current density gradually decreased with potential in the A-P region; this suggested the activation of $\mathrm{Fe}^{2+}$ oxidation and the formation of the passive film. Furthermore, the cathodic reactions for the $\mathrm{NO}_{2}{ }^{-}$/ $\mathrm{HNO}_{2}$ reduction played a critical role in the abovementioned process. ${ }^{28-31}$ On the other hand, the metallurgical phenomenon of the grain boundary segregation (GBS) was generally present 


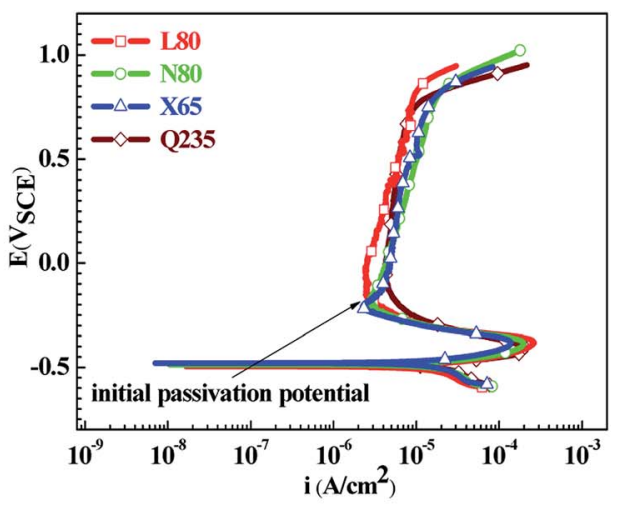

(a)

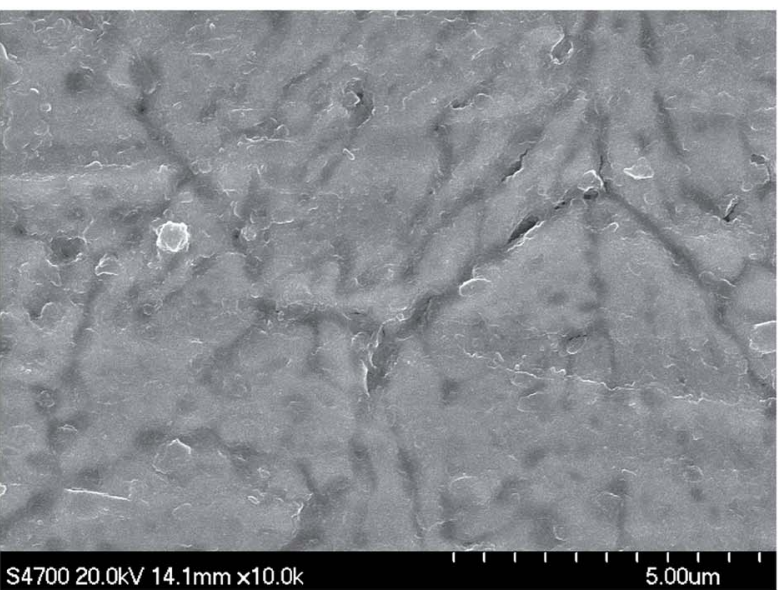

(b)

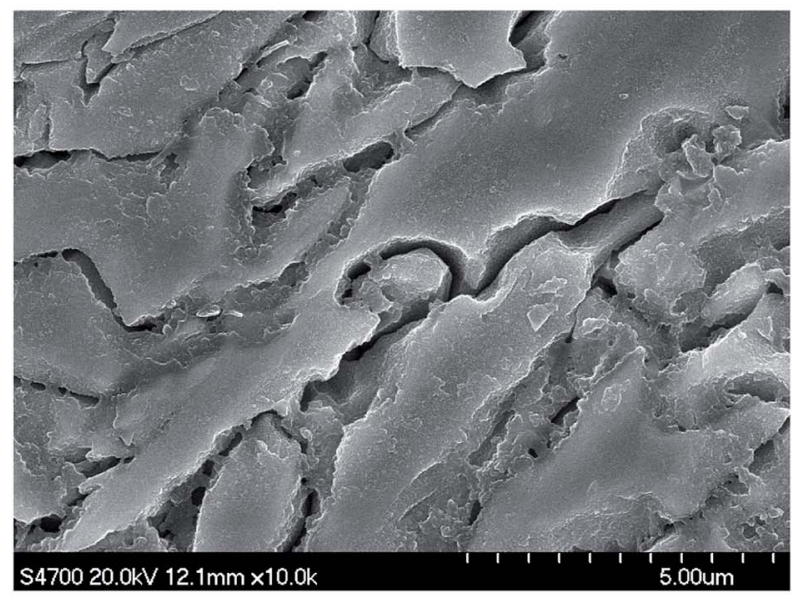

(d)

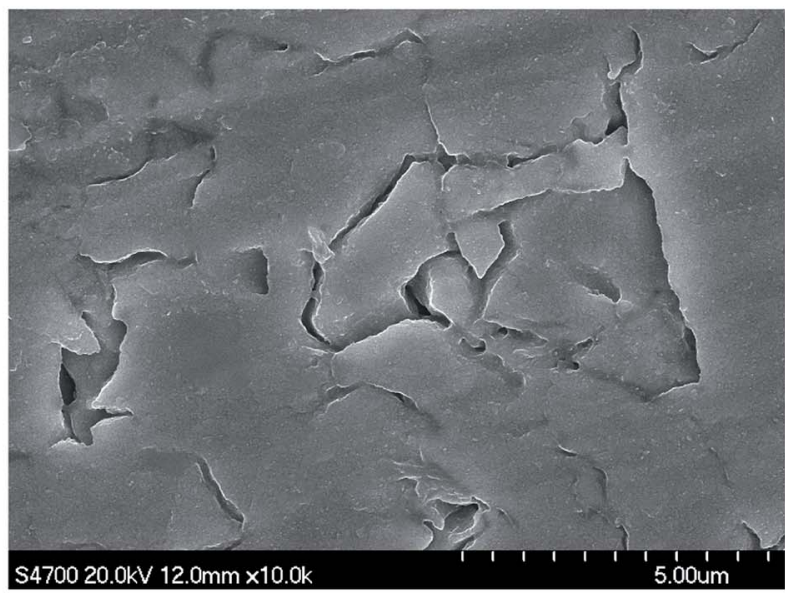

(c)

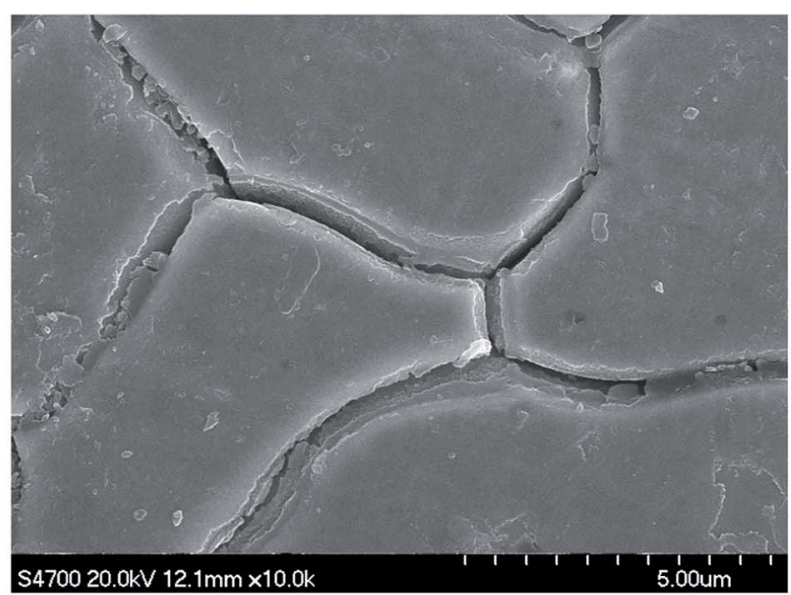

(e)

Fig. 2 Potentiodynamic polarization curves and surface SEM morphologies of the L80, N80, X65 and Q235 steels in a CO $2-\mathrm{NaNO}_{2}$ solution: (a) potentiodynamic polarization curves, (b) L80 SEM image, (c) N80 SEM image, (d) X65 SEM image and (e) Q235 SEM image.

on the alloy steels ${ }^{\mathbf{4 2 - 4 4}}$ and carbon steels, ${ }^{\mathbf{4 5 - 4 7}}$ which resulted in the difference between passivation capabilities of GIs and GBs. ${ }^{48-50}$ In a previous study, it has been reported that GIs containing high level of Fe showed better passivation capability than GBs with high levels of Si and Mn. ${ }^{28}$ Therefore, when the applied potential moved to the A-P region, the electrochemical micro-couple between the GIs and GBs was established spontaneously to induce the occurrence of GBD. However, between the GIs and the GBs, the detailed mechanisms about the establishment of the electrochemical micro-couple and the driving force for the potential difference need further investigation. 


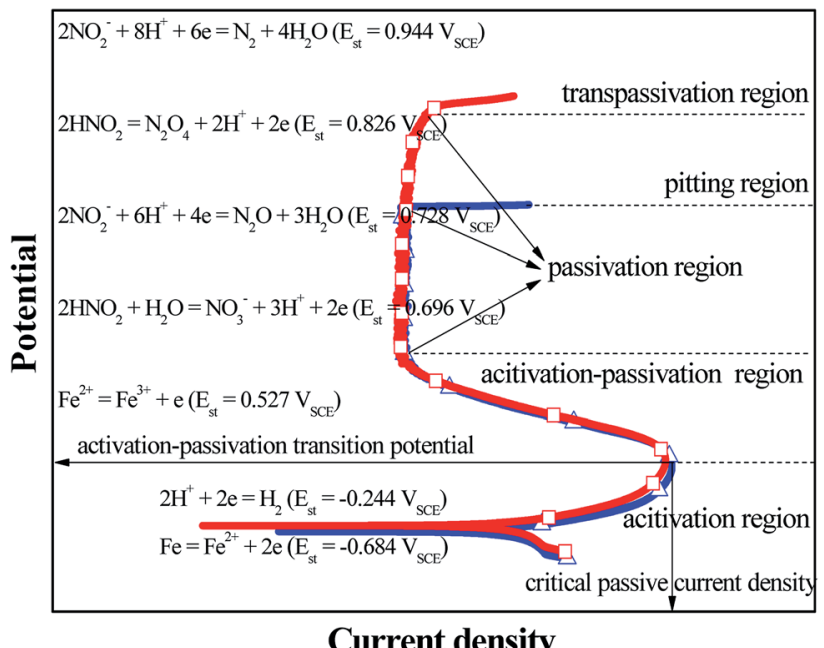

Current density

Fig. 3 Schematic describing the electrode reactions occurring in the A region and $\mathrm{A}-\mathrm{P}$ region.

\section{Conclusions}

In this study, four steels (L80, N80, X65 and Q235) were investigated in four acidic solutions $\left(\mathrm{HNO}_{3}, \mathrm{HCl}, \mathrm{HAc}\right.$ and $\left.\mathrm{CO}_{2}\right)$ containing $\mathrm{NO}_{2}{ }^{-}$to reveal the relationship between the electrochemical characteristic of the A-P transition and the occurrence of GBD. The main conclusions were as follows:

(1) The relationship between the A-P transition and GBD was very close. The appearance of the A-P transition in the PPC indicated the occurrence of GBD on the steel surface. Moreover, it was confirmed that under the electrochemical characteristic of the A-P transition, the occurrence of GBD was a general corrosion behavior for carbon steels and alloy steels in acidic media containing $\mathrm{NO}_{2}{ }^{-}$.

(2) The effect of the steel type on the electrochemical characteristic of the A-P transition and the occurrence of GBD was not obvious. However, the effects of acid type and $\mathrm{pH}$ value were very significant. The A-P transition and the GBD were present from $\mathrm{pH} 1$ to $\mathrm{pH} 4$ in the $\mathrm{HNO}_{3}-\mathrm{NaNO}_{2}$ solutions, at $\mathrm{pH} 3$ and $\mathrm{pH} 4$ in the $\mathrm{HCl}-\mathrm{NaNO}_{2}$ solutions and at $\mathrm{pH} 3$ and $\mathrm{pH} 4$ in the HAc- $\mathrm{NaNO}_{2}$ solutions.

\section{Conflicts of interest}

There are no conflicts to declare.

\section{Acknowledgements}

This work was supported by the National Natural Science Foundation of China (Contract 51601133).

\section{References}

1 B. Feng, Y. H. Kang, Y. H. Sun, Y. Yang and X. Z. Yan, Int. J. Appl. Electromagn. Mech., 2016, 52, 357-362.
2 X. T. Zheng, K. W. Wu, W. Wang, J. Y. Yu, J. M. Xu and L. W. Ma, Nucl. Eng. Des., 2017, 314, 285-292.

3 J. Shi, J. F. Shi, H. X. Chen, Y. B. He, Q. J. Wang and Y. Zhang, J. Pressure Vessel Technol., 2018, 140, 031404.

4 H. L. Huang and J. Tian, Microelectron. Reliab., 2017, 78, 131142.

5 S. Y. Jiang, H. Q. Ding and J. Xu, J. Tribol., 2017, 139, 014501.

6 H. L. Huang, Z. Q. Pan, Y. B. Qiu and X. P. Guo, Microelectron. Reliab., 2013, 53, 1149-1158.

7 X. H. Qiu and W. Wang, Journal of Water Process Engineering, 2017, 17, 271-276.

8 F. G. Deng, L. S. Wang, Y. Zhou, X. H. Gong, X. P. Zhao, T. Hu and C. G. Wu, RSC Adv., 2017, 7, 48876-48893.

9 F. X. Chen, S. L. Xie, X. L. Huang and X. H. Qiu, J. Hazard. Mater., 2017, 322, 152-162.

10 B. R. Linter and G. T. Burstein, Corros. Sci., 1999, 41, 117139.

11 C. N. Cao, Principles of Electrochemistry of Corrosion, Chemical Industry Press, Beijing, 2008.

12 H. W. Liu and Y. F. Cheng, Corros. Sci., 2018, 133, 178-189.

13 Y. Zhou, P. Zhang, Y. Zuo, D. Liu and Y. A. Yan, J. Braz. Chem. Soc., 2017, 28, 2490-2499.

14 J. Rodriguez, L. Chenoy, A. Roobroeck and M. G. Olivier, Corros. Sci., 2016, 108, 47-59.

15 D. L. Engelberg, Shreir's corrosion, vol. 2, 2010, pp. 810-827. 16 J. Qian, C. F. Chen, H. B. Yu, F. Liu, H. Yang and Z. H. Zhang, Corros. Sci., 2016, 111, 352-361.

17 X. J. Qin, X. L. Guo, J. Q. Lu, L. Y. Chen, J. N. Qin and W. J. Lu, J. Alloys Compd., 2017, 698, 1094-1101.

18 X. G. Feng, X. Y. Lu, Y. Zuo, N. Zhuang and D. Chen, Corros. Sci., 2016, 103, 223-229.

19 S. H. Jeon, D. H. Hur, H. J. Kim and Y. S. Park, Corros. Sci., 2015, 90, 313-322.

20 H. Zhao, Z. Y. Zhang, H. Z. Zhang, J. Hu and J. Li, J. Alloys Compd., 2016, 672, 147-154.

21 Z. X. Wang, P. Chen, H. Li, B. J. Fang, R. G. Song and Z. Q. Zheng, Corros. Sci., 2017, 114, 156-168.

22 H. Li, P. P. Zhao, Z. X. Wang, Q. Z. Mao, B. J. Fang, R. G. Song and Z. Q. Zheng, Corros. Sci., 2016, 107, 113-122.

23 J. F. Li, N. Birbills, D. Y. Liu, Y. L. Chen, X. H. Zhang and C. Cai, Corros. Sci., 2016, 105, 44-57.

24 C. Cao, D. Zhang, X. Wang, Q. B. Ma, L. Z. Zhuang and J. S. Zhang, Mater. Charact., 2016, 122, 177-182.

25 X. Y. Liu, M. J. Li, F. Gao, S. X. Liang, X. L. Zhang and H. X. Cui, J. Alloys Compd., 2015, 639, 263-267.

26 K. Kaneko, T. Fukunaga and K. Yamada, Scr. Mater., 2011, 65, 509-512.

27 Y. Zhou and Y. Zuo, Electrochim. Acta, 2015, 154, 157-165.

28 Y. Zhou and F. A. Yan, Int. J. Electrochem. Sci., 2016, 11, 39763986.

29 R. J. Deng, P. Zhang, X. Y. Zhao, G. Y. Cai, H. Liu, J. P. Xiong and Y. Zhou, J. Braz. Chem. Soc., accepted.

30 Y. Zhou, P. Zhang, H. J. Huang, J. P. Xiong and F. A. Yan, J. Braz. Chem. Soc., 2019, 30, 1688-1696.

31 X. Y. Zhang, C. Di and L. C. Lei, $\mathrm{CO}_{2}$ Corrosion and its Control, Chemical Industry Press, Beijing, 2000. 
32 Y. Zuo, H. T. Wang, J. M. Zhao and J. P. Xiong, Corros. Sci., 2002, 44, 13-24.

33 X. Chen, Q. Y. Xiong, F. Zhu, H. Li, D. Liu, J. P. Xiong and Y. Zhou, Int. J. Eletrochem. Sci., 2018, 13, 1656-1665.

34 Y. Zhou and Y. Zuo, J. Electrochem. Soc., 2015, 162, C47-C54. 35 Z. H. Dong, W. Shi, G. A. Zhang and X. P. Guo, Electrochim. Acta, 2011, 56, 5890-5897.

36 Y. Zhou, H. J. Huang, P. Zhang, D. Liu and F. A. Yan, Surf. Rev. Lett., 2019, 26, 1850218.

37 J. K. Kim, Y. H. Kim, J. S. Lee and K. Y. Kim, Corros. Sci., 2010, 52, 1847-1852.

38 X. J. Li, F. Gui, H. B. Cong, C. S. Brossia and G. S. Frankel, Electrochim. Acta, 2014, 117, 299-309.

39 M. Reffass, R. Sabot, M. Jeannin, C. Berziou and Ph. Refait, Electrochim. Acta, 2007, 52, 7599-7606.

40 L. C. Chen, P. Zhang, Q. Y. Xiong, P. Zhao, J. P. Xiong and Y. Zhou, Int. J. Electrochem. Sci., 2019, 14, 919-928.

41 M. B. Valcarce and M. Vazquez, Electrochim. Acta, 2008, 53, 5007-5015.
42 X. H. Guo, Y. D. Zhang, S. B. Jin, R. Hu, Z. W. Liu, R. Q. Zhang and G. Sha, Mater. Chem. Phys., 2019, 236, 121783.

43 Y. J. Kwon, H. J. Seo, J. N. Kim and C. S. Lee, Corros. Sci., 2018, 142, 213-221.

44 T. Kaneshita, G. Miyamoto and T. Furuhara, Acta Mater., 2017, 127, 368-378.

45 M. Kadowaki, L. Muto, H. Katayama, H. Masuda, Y. Sugawara and N. Hara, Corros. Sci., 2019, 154, 159-177.

46 J. C. Han, J. B. Seol, M. Jafari, J. E. Kim, S. J. Seo and C. G. Park, Mater. Charact., 2018, 145, 454-460.

47 Y. Li, W. Li, N. Min, W. Q. Liu and X. J. Jin, Acta Mater., 2017, 139, 96-108.

48 S. Zhang, Y. Wang, H. Jiang and J. Q. Zhou, Meccanica, 2013, 48, 175-185.

49 A. Y. Chen, W. F. Hu, D. Wang, Y. K. Zhu, P. Wang, J. H. Yang, X. Y. Wang, J. F. Gu and J. Lu, Scr. Mater., 2017, 130, 264-268.

50 S. H. Dong, J. Q. Zhou and D. Hui, Int. J. Mech. Sci., 2015, 101, 29-37. 